\title{
A Procedural Treatment of Derivative Suit Dismissals by Minority Directors
}

When a corporation suffers a legal harm, it is the corporation itself, as an independent legal entity, that has a cause of action on that harm. Since the board of directors is the corporation's legal representative, the decision whether to pursue the cause of action is usually left to the board. At the same time, the shareholders of the corporation have important, although indirect, rights in the cause of action, since the value of their shares will be affected by the board's decision whether or not to bring suit. Under American corporation law, the shareholders' interests are protected through the availability of the shareholder derivative suit. If any shareholder feels that the board, by not bringing an available action, is not protecting his interests sufficiently, he can bring the suit in his own name on behalf of the corporation.

One prerequisite to the bringing of a derivative action, known as the deinand requireinent, ${ }^{1}$ is that the shareholders request the board of directors to bring the suit on behalf of the corporation. The demand requirement is based on the assumption that the board usually should decide whether bringing suit would be in the best interests of the corporation. It is often fatal to the derivative suit. If the plaintiff cannot show that the board would not pursue the alleged claim, he cannot prove any harm to his interests, and the court must dismiss the suit. ${ }^{2}$ If, on the other hand, the shareholder presents his claim to the board and it decides not to pursue the action, the court generally will honor that decision and will dismiss the derivative action on the basis of the business judgment rule. ${ }^{3}$ The business judgment rule provides that the board of directors is the primary decisionmaker on matters of corporate management and operation, and that the courts will not inquire into the decisions made in the sound discretion of the board. ${ }^{4}$ The decision

1. For a recent review of the demand requirement, see Comment, The Demand and Standing Reguirements in Stockholder Derivative Actions, 44 U. CHI. L. Rev. 168 (1976).

2. In re Kauffman Mut. Fund Actions, 479 F.2d 257 (Ist Cir.), cert. denied, 414 U.S. 857 (1973); Brooks v. American Export Indus., 68 F.R.D. 506 (S.D.N.Y. 1975).

3. United Copper Sec. Co. v. Amalgamated Copper Co., 244 U.S. 261 (1917); Corbus v. Alaska Treadwell Gold Mining Co., 187 U.S. 455 (1903).

4. "The business judgment rule originated as a means of limiting the liability of corporate directors and officers for mistakes made while performing their duties. Absent bad faith or some other corrupt motive, directors are normally not liable to the corporation for mistakes of judgment." Cramer v. General Tel. \& Elec. Corp., 582 F.2d 259, 274 (3d Cir. 1978). The rule would not seem, then, to apply to the decision of the directors not to pursue a lawsuit, since they are in no 
whether to sue on a legal claim is such a decision.

However, demand on the directors is not always required for the maintenance of a derivative action. The federal courts have long held that demand is unnecessary if the making of such a demand would be futile. One instance in which demand would be futile is where more than half of the directors are themselves defendants in the suit. ${ }^{5}$ In such a case, the board of directors is "tainted" by the interest of its members in the events giving rise to the suit. They are unlikely to investigate the feasibility of the proposed suit objectively, and will in most cases reject the shareholder's request on the basis of personal rather than corporate interests. Such an exercise in futility is not required.

In several recent cases, however, federal courts in essence have reversed this aspect of the futility exception. ${ }^{6}$ In each of these cases a shareholder had brought a derivative action against a group of defendants that included a majority of the corporation's board of directors. In keeping with precedent, the courts did not require the plaintiff to make a demand on the board. In each case, however, the board formed a "special hitigation committee," composed of those directors who were not defendants in the derivative suit (a minority of the board as a whole), and empowered that committee to decide whether to pursue the action or not. In every case, the committee decided not to pursue the action, and asked the trial court to dismiss the derivative suit. The courts applied the busmess judgment rule to the committees' decisions and, based on those decisions, dismissed the suits.

This Comment will demonstrate that the business judgment of these litigation committees, like that of the tainted boards of which they were a part, does not deserve such judicial deference. Thus, these cases conflict with precedent, which had refused to grant a board dominated by defendants to a derivative suit the authority to compel dismissal of

danger of personal liability for that decision. In theory, a later suit could seek to hold them hable for the results of the decision, and that suit would present an opportunity for a normal application of the rule. The federal courts, however, have long applied the business judgment rule to bar shareholder derivative suits when the board las refused the demand by the plaintiff. See id; Dent, The Power of Directors to Terminate Shareholder Litigation: The Death of the Derivative Suit?, 75 Nw. U.L. REv. 96, 101-02 (1980).

The courts lrave held, under this application of the business judgment rule, that they will not "second guess" a decision of the board of directors unade in good faith, H. HENN, HANDBOOK OF THE LAW OF CORPORATIONS AND OTHER BUSINESS ENTERPRISES 482 (1970), which means that to be questioned the directors' action inust at least border on "fraud, illegality or conflict of interest," Shlensky v. Wrigley, 95 Ill. App. 2d 173, 181, 237 N.E.2d 776, 780 (1968).

5. Meltzer v. Atlantic Research Corp., 330 F.2d 946 (4th Cir.), cert, denied, 379 U.S. 841 (1964); Cathedral Estates v. Taft Realty Corp., 228 F.2d 85 (2d Cir. 1955); Galfand v. Chestnutt Corp., 402 F. Supp. 1318 (S.D.N.Y. 1975), modified, 545 F.2d 807 (2d Cir. 1976), cerr. denied, 435 U.S. 943 (1978).

6. See cases listed at note 25 infra. 
that suit. In order to msure fairness, the courts must reach the merits of these cases. The busmess judgment rule is ill-suited for use as a justification for their automatic dismissal.

Several commentators have suggested that $\mathrm{m}$ order to deal with this problem, the use of the busmess judgment rule in these cases should be abandoned. 7 The application of the rule is a product of substantive state law, however, and any change in its use must occur at the state level. ${ }^{8}$ Since the adoption of the suggested changes would be up to the legislatures and courts of every state, any change in the law would be likely to take years to effect, and would result in a wide variation in the rules enacted.

This Comment advocates a more efficient and satisfactory solution to the problem. Most shareholder derivative suits are brought in the federal courts, and are therefore subject to the Federal Rules of Civil Procedure. ${ }^{9}$ By treating the litigation committee's motion to dismiss as a proposal for settlement under Rule 23.1, the courts can give the merits of these cases the limited review that they deserve, rather than automatically dismissing them or allowing them to go to trial. Such a procedure is required by the policies behind Rule 23.1. Moreover, the federal courts have interpreted this rule such that its application in the minority directors cases would be practical and consistent with its apphication in other cases.

In developing this proposal, Part I of this Comment discusses the development and current status of the demand requirement and the relationship of the recent cases to that requirement. Part II exammes why the busimess judgment rule cannot be safely applied to the decisions of minority directors to call for the dismissal of a suit against the board majority. Finally, Part III analyzes the policies and precedents applicable to Rule 23.1, the Supreme Court's rejection of the settlement procedure in Burks v. Lasker, ${ }^{10}$ and the advantages of its use in minority director cases.

7. See Block \& Barton, The Business Judgment Rule as Applied to Proxy Derivative Suits Under the Securities Exchange Act, 8 SEC. REG. L.J. 99 (1980); Dent, supra note 4; Note, The Business Judgment Rule in Derivative Suits Against Directors, 65 CORNeLL L. REv. 600 (1980); Comment, Director, Judge Thyself-The "Independent" Director and Dismissal of a Shareholder Suit in Lewis v. Anderson, 1980 UTAH L. REv. 601.

8. This was the holding in Burks v. Lasker, 441 U.S. 471 (1979). See text accompanying notes 37-45 infra.

9. At least eight cases involving motions by minority directors have been brought in the federal courts, while the courts of only two states have dealt with this situation. See cases cited in notes $25,78,80$ infra. Also, the Securities Exchange Act of 1934, which governs suits for fraud, 15 U.S.C. $\$ 78 \mathrm{j}(\mathrm{b})$ (1976), and proxy violations, id. $\& 78 \mathrm{~h}(\mathrm{a})$, grants exclusive jurisdiction to the federal courts. Id. § 78 aa.

10. 441 U.S. 471 (1979). 
Recent Developments and the Demand Requirement

\section{A. Derivative Suits and the Need for Demand}

A basic requirement in the federal courts is that an action must be brought by or for the party that has a real interest in it. ${ }^{11}$ Ordimarily this means that the action must be brought by the injured party or a representative of that party. The rule does not apply, however, where the party in interest is a publicly-held corporation. ${ }^{12}$ Conflicts may arise within a corporation due to the separation of ultimate ownership from immediate control. When a corporation is harmed, the shareholders, as ultimate owners, also suffer and may want to bring suit; yet the board of directors, which has a more immediate control over the corporation's operation, may frustrate this desire if it decides not to pursue the action.

The courts resolved this problem by creating the shareholder derivative suit, permitting the shareholder to bring suit in the imterest of the corporation, although not in the name of the corporation. The corporation, as a separate legal person, must be a party to this suit; simce the plaimtiff is attemptimg to force the corporation to pursue its cause of action, the federal rules require that the corporation be designated a defendant. ${ }^{13}$

In the early case of Hawes $v$. Oakland, ${ }^{14}$ the Umited States Supreme Court set the boundaries of the derivative action. A principal requirement for brimging such a suit is that the plaintiff exhaust his remedies within the corporation before going to court. The basic component of this is the requirement that the shareholder demand of the directors that they bring the suit in the corporation's naine. ${ }^{15}$ The courts have inaintained this requirement, and it has since been incorporated into the Federal Rules of Civil Procedure. It is presently found in Rule 23.1. ${ }^{16}$

11. FED. R. Crv. P. 17.

12. Smith v. Sperling, 117 F. Supp. 781 (S.D. Cal. 1953) (exception to Rule 17 made for shareholder derivative suits), rev'd on other grounds, 354 U.S. 91 (1957).

13. See Fed. R. Civ. P. 19(a).

14. 104 U.S. 450 (1881).

15. Id. at $460-61$.

16. Rule 23.1 states:

In a derivative action brought by one or more shareholders or members to enforce a right of a corporation or of an unincorporated association, the corporation or association having failed to enforce a right which may properly be asserted by it, the complaint shall be verified and shall allege (1) that the plaintiff was a shareholder or member at the time of the transaction of which he complains or that his share or membership thereafter devolved on him by operation of law, and (2) that the action is not a collusive one to confer jurisdiction on a court of the United States which it would not otherwise have. The complaint shall also allege with particularity the efforts, if any, made by the plamtiff to obtain the action he desires from the directors or comparable authority and, if neces- 
Rule 23.1 states the demand requirement simply: "The complaint shall also allege with particularity the efforts, if any, made by the plaintiff to obtain the action he desires from the directors or comparable authority . . . and the reasons for his failure to obtain the action or for not making the effort." Unfortunately, the brevity of the rule has not resulted in a clear and consistent apphication of its requirements.

Since demand is not required in all cases, and when it is required it often signals the end of a shareholder suit, determining the circumstances under which demand is not required is extremely important. Unfortunately, the courts have not defined these circumstances adequately. Rather than formulating a usable set of guidelines, the courts have simply relied on the catchword "futility."17 Plaintiffs generally have sought to satisfy the futility test by claiming that the board would refuse any demand because the directors are themselves defendants or are under the control of the defendants. The pleadings required to excuse demand vary considerably. A few courts have held that an allegation that the defendants control the majority of the board is sufficient; ${ }^{18}$ most courts, however, have required greater detail. ${ }^{19}$ Similarly, some courts have excused demand when a majority of the directors have acquiesced in the transaction underlying the action. ${ }^{20}$ One court, however, has indicated that demand on the board would be excused only if the majority of directors were imterested in the transaction, not just acquiescent in it. ${ }^{21}$

Even under the strictest application of the demand requirement, the courts have not required a demand where a majority of the board are defendants in the underlying cause of action. Thus, where a majority of the directors will be subject to liability if the suit succeeds, the

sary, from the shareholders or nembers, and the reasons for his failure to obtain the action or for not making the effort. The derivative action may not be maintained if it appears that the plaintiff does not fairly and adequately represent the interests of the shareholders or members similarly situated in enforcing the rights of the corporation or association. The action shall not be dismissed or compromised without the approval of the court, and notice of the proposed dismissal or compromise shall be given to shareholders or members in such manner as the court directs.

17. See 3B Moore's Federal Practice I 23.1.19, at 23.1-87 (2d ed. 1976); 7A C. Wright \& A. Miller, Federal Practice and Procedure $\S 1831$, at 379-80 (2d ed. 1972), $237-38$ (Supp. 1980), and cases cited therein.

18. Liboff v. Wolfson, 437 F.2d 121 (5th Cir. 1971); Papilsky v. Berndt, 59 F.R.D. 95 (S.D.N.Y. 1973), appeal dismissed, 503 F.2d 554 (2d Cir.), cert. denied, 419 U.S. 1048 (1974); $c f$. Delaware \& Hudson Co. v. Albany \& S. R.R., 213 U.S. 435 (1909) (defendant owned a inajority of the stock of the corporation); Treves v. Servel, Inc., 244 F. Supp. 773 (S.D.N.Y. 1965) (same).

19. See Brody v. Chemical Bank, 482 F.2d 1111 (2d Cir. 1973) (plaintiff's assertion that new directors were related to predecessors insufficient).

20. Meltzer v. Atlantic Research Corp., 330 F.2d 946 (4th Cir.), cert. denied, 379 U.S. 841 (1964); Papilsky v. Berndt, 59 F.R.D. 95 (S.D.N.Y. 1973), appeal dismissed, 503 F.2d 554 (2d Cir.), cert. denied, 419 U.S. 1048 (1974).

21. In re Kauffman Mut. Fund Actions, 479 F.2d 257 (1st Cir.), cert. denied, 414 U.S. 857 (1973). See also Brooks v. American Export Indus., Inc., 68 F.R.D. 506 (S.D.N.Y. 1975). 
courts have uniformly excused demand. ${ }^{22}$

\section{B. The Minority Directors Cases}

The courts have confronted this situation in several recent cases in which the relevant boards of directors could not petition for a dismissal of derivative actions on the basis of the demand requirement rule because a majority of the directors were named defendants to the underlying cause of action. In each of these cases, however, the board delegated its decisionmaking authority to a special litigation committee composed of those directors who were not named as defendants. ${ }^{23}$ These committees, upon deciding not to pursue the actions, did not attempt to invoke the deinand requirement and terminate the suits based

22. Delaware \& Hudson Co. v. Albany \& S. R.R., 213 U.S. 435 (1909); Meltzer v. Atlantic Research Corp., 330 F.2d 946 (4th Cir.), cert. denied, 379 U.S. 841 (1964).

23. The authority of the directors depends generally on state law. Most states require that half or more of the directors be present before the board conduct busimess, e.g., ILL. ANN. STAT. ch. 32, § 157.37 (Smith-Hurd 1979); 15 PA. Cons. STAT. ANN. § 402 (Purdon 1968); Tex. Bus. CORP. ACT ANN. art. 2.35 (Vernon 1973); VA. CODE \& 13.1-39 (1978), while other states permit no less than a third of the directors to conduct business, e.g., CAL. CORP. CODE $\S 307$ (Deerimg Supp. 1980); Conn. Gen. Stat. ANN. § 33-316 (West Supp. 1979); Del. Code ANN. tit. 8, \& 141 (1974); N.J. Stat. ANN. § 14A:6-7 (West 1973); N.Y. Bus. CoRp. LAw $§ 707$ (McKinney 1963). Since these states acknowledge as an act of the board the action of a majority of those present at a meeting at which there is a quorum, at least a sixth, and more generally a quarter of the directors would have to concur in order to adopt a resolution. This requirement is not a real barrier to action by minority directors, and to the extent that it does impede action, it can be avoided through a provision in virtually every state law that empowers the board of directors to delegatc most or all of its authority to one or more committees of the board. ALA. CODE $\$ 10-2-57$ (1975); AlaSKa STat. § 10.05.195 (1968); ARIZ. Rev. Stat. ANN. § 10-042 (1977); ARK. STAT. ANN. § 64306 (1966); Cal. CoRP. Code \$ 311 (Deering Supp. 1980); Colo. Rev. STAT. \$ 7-5-107 (Supp. 1978); Conn. Gen. Stat. ANN. § 33-318 (West Supp. 1977); Del. Code ANN. tit. 8, § 141 (1974); D.C. Code ANN. § 916e (1973); Fla. Stat. ANN. § 607.127 (West 1977); Ga. Code ANN. § 22708 (1977); Hawall REv. STAT. § 416-80 (1976); IDaho Code § 30-I-42 (1980); Ill. ANN. STAT. ch. 32, § 157.38 (Smith-Hurd 1979); IND. CODE § 23-1-2-11 (1979); IOWA CODE ANN. § 496A.39 (West Supp. 1980); KaN. Stat. ANN. § 17-6301 (1974); KY. REv. STAT. § 271A.210 (Supp. 1980); La. Rev. Stat. ANN. § 12:81 (West 1968); Me. Rev. Stat. ANN. tit. 13-A, § 713 (Supp. 1980); MD. CoRP. \& Ass'NS CODE ANN. \$ 2-411 (1975); MASs. GEN. LAws ANN. ch. 156, § 26 (West 1970); Mich. Comp. Laws ANN. $\$ 450.1527$ (1973); Minn. Stat. ANN. $\$ 301.28$ (West Supp. 1979); Miss. Code ANN. § 79-3-79 (1972); Mo. ANN. STAT. § 351.330 (Vernon 1966); MoNT. Rev. Codes AnN. § 35-1-407 (1979); Neb. Rev. Stat. § 21-2041 (1977); Nev. Rev. Stat. $\S 78.125$ (1979); N.H. REv. Stat. ANN. \& 294:89 (1977); N.J. STAT. ANN. § 14A:6-9 (West 1973); N.M. STAT. ANN. § 53-11-41 (1978); N.Y. Bus. CoRP. LAw \& 712 (McKinney 1977); N.C. GEN. StAT. § 55-31 (1979); N.D. CENT. CODE § 10-19-42 (1957); OHIO Rev. Code ANN. § 1701.63 (Page 1953); OkLa. Stat. ANN. tit. 18, § 1.36 (West 1951); OR. Rev. STat. § 57.206 (1979); 15 PA. Cons. StaT. ANN. § 402 (Purdon 1968); R.I. GEN. LAWs § 7-1.1-38 (1969); S.C. Code § 33-13-100 (1976); S.D. CoMP. LAWs. ANN. § 47-5-13 (1967); TENN. CODE ANN. § 48-810 (1979); TeX. BUS. CORP. ACT ANN. art. 2.36 (Vernon 1975); UTAH CODE ANN. § 16-10-39 (1972); VT. STAT. ANN. tit. 11, § 1886 (1973); VA. CODE $§ 13.1-40$ (Supp. 1980); WASH. Rev. CoDE ANN. § 23A.08.400 (1969); Wis. Stat. ANN. § 180.36 (West Supp. 1980); Wyo. STat. § 17-1-137 (Supp. 1980). West Virginia does not have such a statute. 
on the plaimtiffs' failure to make any demand. ${ }^{24}$ Instead, they sought summary judginent based on the business judgment rule. ${ }^{25}$ The courts accepted this novel apphication of the rule and dismissed the actions, relying heavily on deinand cases that did not involve boards dominated by defendants to the derivative action. ${ }^{26}$ In each case, the court granted a summary judgment that left the shareholder plaintiffs no opportunity to amend the complaints, terminating the corporation's cause of action.

The federal district courts were the first to use the business judgment rule in this manner, in Gall v. Exxon ${ }^{27}$ and Rosengarten v. ITT. ${ }^{28}$ In Gall, an Exxon shareholder alleged that fifty-nine million dollars in bribes and pohitical payments to foreign officials had constituted a waste of corporate assets and a breach of the directors' fiduciary duty, and were violations of sections 13(a) and 14(a) of the Securities Exchange Act of 1934. ${ }^{29}$ The suit named a majority of Exxon's board of directors as defendants, alleging personal comphicity in the illegal acts. In response, the board, in accordance with corporate bylaws, appoimted a "Special Committee on Litigation" composed of three recently selected directors with no involvement in the prior wrongdoing, ${ }^{30}$ and authorized it to review and investigate the cause of action. After a four month investigation, the committee issued an eighty-two page report and directed counsel for Exxon to seek dismissal of the suit.

Corporate connsel moved for a summary judgment based on the

24. See Lasker v. Burks, 404 F. Supp. 1172, 1178 (S.D.N.Y. 1975), rev'd, 567 F.2d 1208 (2d Cir. 1978), rev'd, 441 U.S. 471 (1979).

25. Lewis v. Anderson, 615 F.2d 778 (9th Cir. 1979), cert. denied, 100 S. Ct. 206 (1980); Genzer v. Cunningham, 498 F. Supp. 682, 683 (E.D. Mich. 1980); Maldonado v. Flynn, [19791980 Transfer Binder] FED. SEC. L. REP. (CCH) ๆ 97,260 (S.D.N.Y. Jan. 24, 1980); Rosengarten v. ITT, 466 F. Supp. 817, 819-20 (S.D.N.Y. 1979); Abbey v. Control Data Corp., 460 F. Supp. 1242, 1243 (D. Minn. 1978), affd, 603 F.2d 724 (8th Cir. 1979), cert. denied, 444 U.S. 1017 (1980); Gall v. Exxon, 418 F. Supp. 508, 509 (S.D.N.Y. 1976); Lasker v. Burks, 404 F. Supp. 1172, 1174 (S.D.N.Y. 1975), rev'd, 567 F.2d 1208 (2d Cir. 1978), rev'd, 441 U.S. 471 (1979); Auerbach v. Bennett, 64 A.D.2d 98, 102-03, 408 N.Y.S.2d 83, 85 (1978), modified, 47 N.Y.2d 619, 393 N.E.2d 994, 419 N.Y.S.2d 920 (1979).

26. See, e.g., Rosengarten v. ITT, 466 F. Supp. 817, 822-24 (S.D.N.Y. 1979); Gall v. Exxon, 418 F. Supp. 508, 515 (S.D.N.Y. 1976).

27. 418 F. Supp. 508 (S.D.N.Y. 1976). In fact, ten months before the Gall decision, the district court in Lasker v. Burks reached a similar disposition. 404 F. Supp. 1172 (S.D.N.Y. 1975), rev'd, 567 F.2d 1208 (2d Cir. 1978), rev'd, 441 U.S. 471 (1979). The facts in Lasker do not present as good an example of the problem, however, since the real defendants did not constitute a majority of the board, and the "disinterested directors" did constitute a quorum of the whole board, so that a committee was not needed. 404 F. Supp. at 1175.

28. 466 F. Supp. 817 (S.D.N.Y. 1979).

29. 15 U.S.C. $\$ 878 \mathrm{~m}, 78 \mathrm{n}(1976)$.

30. The three directors were Jack F. Bennett, who had been an Under Secretary of the United States Treasury Department before becoming a director and had been an einployee of Exxon before that, Richard P. Dobson, the chairman and chief executive officer of British-American Tobacco Company, Ltd., and Edward G. Harness, the chairman of the board and chief executive officer of the Proctor \& Gamble Company. 418 F. Supp. 508, 510 n.2. 
business judgment rule. The court concluded that: "[A]bsent allegations of fraud, collusion, self-interest, dishonesty or other misconduct of a breach of trust nature, and absent allegations that the business judgment exercised was grossly unsound, the court should not at the mstigation of a single shareholder interfere with the judginent of the corporate officers." 31 The court withheld summary judgment only to see whether the plaintiff could prove such a breach of trust.

The Gall court treated the business judgment rule as if it were a rule of federal law; it did not mention the law of New Jersey, and cited only federal cases $^{32}$ - cases that concerned corporations froin at least seven separate states. Previously, the district court in Lasker v. Burks ${ }^{33}$ had also reasoned froin federal cases, ${ }^{34}$ using almost the same cases as the Gall court. Later, in Rosengarten, the court considered both state and federal versions of the business judgment rule. ${ }^{35}$ And in Cramer $v$. General Telephone and Electronics Corp., in which demand on the board was necessary, the court specifically raised the question whether the use of the business judgment rule was governed by state or federal law, but refused to decide it. ${ }^{36}$

Finally, in Burks v. Lasker, ${ }^{37}$ the United States Supreme Court apparently foreclosed any possibility that the courts could formulate a uniform federal rule to govern the minority dircctor cases. The Court held that in the absence of a conflict with federal policy, state law controls the capacity of dismterested mimority directors to dismiss, in federal court, a nonfrivolous derivative suit agamst the board majority. ${ }^{38}$ Burks involved claims arismg under the Investinent Advisers Act of $1940^{39}$ and the Investinent Company Act of $1940,{ }^{40}$ both federal statutes. Thus, the Court did not rely on the liolding of Erie Railroad Co. $v$. Tompkins, ${ }^{41}$ which requires federal courts to apply state substantive

31. $418 \mathrm{~F}$. Supp. at 516 .

32. Id. at 515-16.

33. 404 F. Supp. 1172 (S.D.N.Y. 1975), rev'd, 567 F.2d 1208 (2d Cir. 1978), rev'd, 441 U.S. 471 (1979).

34. $404 \mathrm{~F}$. Supp. at 1178.

35. $466 \mathrm{~F}$. Supp. at $822-24$.

36. 582 F.2d 259, $275-76$ (3d Cir. 1978), cert. denied, 439 U.S. 1129 (1979).

37. 441 U.S. 471 (1979).

38. Id. at 477-80. A number of lower federal courts have adopted the Supreme Court's approach. See Lewis v. Anderson, 615 F.2d 778 (9th Cir. 1979), cert. denied, 100 S. Ct. 206 (1980); Abbey v. Control Data Corp., 603 F.2d 724 (8th Cir. 1979), cert. denied, 444 U.S. 1017 (1980); Genzer v. Cunningham, 498 F. Supp. 682 (E.D. Mich. 1980); Maldonado v. Flynn, [1979-1980 Transfer Binder] FED. SEC. L. REP. (CCH) \ 97,260 (S.D.N.Y. Jan. 24, 1980). Similar facts were presented in Cramer v. General Tel. \& Elec. Corp., 582 F.2d 259 (3d Cir. 1978), cert. denied, 439 U.S. 1129 (1979), but the case was decided on other grounds.

39. 15 U.S.C. $\S \S 80 b-1$ to $80 b-21$ (1976 \& Supp. III 1979).

40. Id. $\$ \S 80 \mathrm{a}-1$ to $80 \mathrm{a}-52$.

41. 304 U.S. 64 (1938). 
law in cases in which jurisdiction is based on diversity of citizenship. ${ }^{42}$ Instead, the Court held that the Acts were "generally enacted against the background of existing state law"43 and that the question of the powers of the minority directors was one for state law, since Congress had not addressed it.

After Burks, state substantive law governs the power of a committee of minority disinterested directors to terminate a derivative suit, except in those few instances in which federal policy inandates a particular result. ${ }^{44}$ Moreover, the Burks Court rejected the plaintiff's contention that federal procedural law should govern the treatinent of the committee's request for dismissal. The plaintiff had argued that the Court should apply the Rule 23.1 settlement procedure advocated in this Comment to the request. The Court rejected this argument in a footnote, ${ }^{45}$ concluding that the procedure applies only in cases involving voluntary settleinents between derivative plaintiffs and defendants, while Burks involved an involuntary dismissal of an action by a court.

To sumınarize, inost of the minority director cases liave treated the litigation committees' requests for dismissal as they would a vote of a disinterested board not to pursue a lawsuit. They have accorded these requests the deference of the business judgment rule, which has resulted in the dismissal of the actions. The courts have failed to explain, however, why the business judgment rule, normally applied only to disinterested boards at the deinand stage of an action, should be applied in such a novel way to committees formed from essentially interested boards, in actions in which demand lias already been excused. The Burks Court was correct in loolding that state law governs the creation and authority of committees of the board of directors, but it was wrong to allow such law to override the dictates of federal procedural law. In fact, the suminary judgments granted in these cases violate the policies underlying the notice requireinent of Rule 23.1, which should be applied.

42. Burks v. Lasker, 441 U.S. 471, 476 (1979).

43. Id. at 478 .

44. The question of what policies are embodied in a federal statute is itself difficult and uncertain. The court in Lewis v. Anderson, 615 F.2d 778 (9th Cir. 1979), cert. denied, 101 S. Ct. 206 (1980), held that § 14(a) of the Securities Exchange Act of 1934, 15 U.S.C. § 78n (1976), promoted no policy sufficient to preclude the use of state law in determining the authority of a minority committee of directors. Subsequently, in Galef v. Alexander, 615 F.2d 51 (2d Cir. 1980), the court held that the use of state law to grant summary judgment would undermine the intent of the sane provision. However, Galef is not exactly on point with Lewis, since it did not involve a committee of minority directors. See Cominent, supra note 7, at 610-12 (discussing the conflict between the two opinions).

Also, of course, federal policies may vary substantially between statutes, so that even among cases in which federal standards apply there may be no uniformity in the standards used.

45. 441 U.S. at 485 n.16. 
II

\section{DEFERENCE TO THE RECOMMENDATIONS OF MINORITY DIRECTORS}

In each of the mimority directors cases, the special hitigation committees were composed entirely of outside directors, ${ }^{46}$ meaning that they were not employees of the corporations that they imvestigated. While this may not always be the case, there are substantial reasons to expect that it usually will occur. As a consequence of the offices they hold within the corporation, inside directors have relatively broader duties to the corporation, and therefore have a greater opportunity to mjure the corporation than do outside directors. This fact may make them more likely to be mvolved in wrongdoing, or at least to know of and acquiesce in it. It certainly makes them more likely to be named as defendants $\mathrm{m}$ shareholder suits than are outside directors. Thus, committees of "disinterested directors" are likely to be composed primarily or solely of outside directors. This practice is sensible since inside directors, even if not themselves defendants, would encounter serious conflicts of interest im imvestigating other insiders, particularly if the insider defendants are their superiors. ${ }^{47}$ The courts seem to recognize this conflict, simce the opinions in the minority directors cases specifically pointed to the use of outside directors in the litigation committees. ${ }^{48}$

For a number of reasons, however, the reassurance of using outside directors is illusory. Outside directors, particularly when they constitute a minority of the board, also encounter significant conflicts when mvestigating other directors. While there have been no studies of outside directors investigating the conduct of imsiders, empirical studies of the operation of boards of directors imdicate that the independence of outsiders is generally minimal because of (1) the control of the proxy machinery by the insiders, (2) the ties of the outsiders to the imsiders, (3) problems inherent in the selection of outside directors, and (4) limitations on outside directors' time and access to information.

46. Exxon did use one inside director in Gall v. Exxon, 418 F. Supp. 508, 510 (S.D.N.Y. 1976), and one of the minority directors was a nominal defendant in Lewis v. Anderson, 615 F.2d 778, 780 (9th Cir. 1979), cert. denied, 100 S. Ct. 206 (1980). In the other cases, the committees were composed entirely of outside directors. Abbey v. Control Data Corp., 603 F.2d 724, 727 (8th Cir. 1979), cert. denied, 444 U.S. 1017 (1980); Genzer v. Cunningham, 498 F. Supp. 682,693 (E.D. Mich. 1980); Maldonado v. Flynn, [1979-1980 Transfer Binder] FEd. SEc. L. REP. (CCH) \ 97,260 at 196,828 (S.D.N.Y. Jan. 24, 1980); Rosengarten v. ITT, 466 F. Supp. 817, 824 (S.D.N.Y. 1979); Lasker v. Burks, 404 F. Supp. 1172, 1179 (S.D.N.Y. 1975), rev'd, 567 F.2d 1208 (2d Cir. 1978), rev'd, 441 U.S. 471 (1979).

47. The Director Looks At His Job (C. Brown \& E. Smith eds. 1957); H. Koontz, The Board of Directors and Effective Management 126-27 (1967); M. MaCe, Directors: MYTH AND REALITY 119-20 (1971).

48. See cases cited in note 46 supra. 


\section{A. Proxy Machinery}

The most important limitation on the independence of minority directors results from the control that the majority holds over the process by which directors are selected. Although the board has the authority to determine whom to nominate for board nembership, it seldom uses that power, leaving the selection of management nominees to the corporation's chief executive. ${ }^{49}$ The chief executive, however, will be likely to be among the inside directors implicated in the derivative suit, and at least will be a colleague of those insiders. If the chief executive wants to remove a director from the board, he can force the director out or he can simply leave his naine off the list of management-recommended candidates at the next board election. ${ }^{50}$

If the disinterested directors constituted a majority of the board, they could protect their interests by taking this power from the chief executive. However, by definition the majority of the directors are defendants in the derivative suit. Thus, the disinterested directors are unable to take away the chief executive's selection power. Moreover, even if the chief executive is not implicated in the suit or otherwise inclined toward removing the committee inembers from the board, the board majority could act on its own to overrule the chief executive, thus keeping the minority's positions in jeopardy.

Some commentators have suggested that the independence of outside directors might be assured if the chief executive would delegate the nomination of directors to a committee controlled by outsiders. ${ }^{51}$ However, management is generally reluctant to relinquish such a power. ${ }^{52}$ Even in the relatively few corporations that have such nomi-

49. J. Bacon \& J. Brown, Corporate Directorship Practices: Role, Selection and Legal Status of THE BOARD 28-29 (The Conference Board Report No. 646, 1975); C. BRowN, Putting the Corporate BoARd to WORK 22-24 (1976); C. BRoWn \& E. SMITH, supra note 50, at 53-55; M. Eisenberg, The Structure of the Corporation-A Legal ANalysis 146 (1976); R. GORDON, BUSINESS LEADERSHIP in tHE LARGE CORPORATION 130, 344-46 (2d ed. 1961); M. MACE, supra note 50, at 77-83; E. MCSweENey, MANAGING THE MANAGers 30 (1978); Moscow, The Independent Director, 28 Bus. LAw. 9, 11 (1972); Soderquist, Toward a More Effective Corporate Board: Reexamining Roles of Outside Directors, 52 N.Y.U. L. Rev. 1341, 1350 (1977); cf. Nutt, A Study of Mutual Fund Independent Directors, 120 U. PA. L. REV. 179, 215-16 (1971) (mutual funds).

50. C. Brown, supra note 49 , at 24,83 ; M. MACE, supra note 47 , at $78-79,94$; E. MCSWEENEY, supra note 49 , at 32.

51. C. BRown, supra note 49, at 83-84; C. Brown \& E. SMITH, supra note 47, at 53.

52. The use of nominating committees has increased, but slowly. In a 1962 survey of 918 corporations, seven had such committees. J. KinLeY, CoRPorate Directorship PraCtices: Studies IN Business Policy 3, 137 (National Industrial Conference Board Report No. 103, 1962). By 1973, a similar survey of 853 corporations found 58 with nommating committees. J. BACON, CORPORATE DIRECTORSHIP PRACTICES: MEMBERSFIP AND COMMITTEes OF THE BOARD, 50-51 (The Conference Board Report No. 588, 1973). "Two possible board actions are so threatening to management that few directors are even willing to discuss them: changing the proxy 
nating committees, the selection of directors is frequently controlled by the chief executive. ${ }^{53}$ To ensure their independence, the minority directors would have to control the nominating committee.

Moreover, management control over the proxy nnachinery makes it likely that directors who show independence will not be asked to sit on other boards of directors. In selecting their boards, corporate management generally looks for directors who will be agreeable, not ones who have "rocked the boat." 54 Thus, a committee decision to pursue an action agamst the majority of the corporation's board of directors will be likely to thwart its members' desires to sit on other boards.

\section{B. Ties to Insiders}

Another factor, not within the control of management, that may color the judginent of outsiders who have been on the board for some time is friendship. A director who has served several years may feel substantial gratitude toward the chief executive, especially since outside directors frequently were friends of the chief executive before their selection to the board. ${ }^{55}$ Those outsiders who were not selected for this reason often have a more material affinity for management. Many outside directors are commercial bankers, attorneys, or investnent bankers for the corporation. ${ }^{56}$ Other outsiders may be tied to the mside directors through interlocking directorates. ${ }^{57}$ All of these outsiders will have worked with the defendants, and may find it difficult to believe that their colleagues have done anything wrong, giving their actions a high presumption of legitimacy or even ignoring evidence of wrongdomg.

Whether this affinity is emotional or economic, the evidence mdicates that most outside directors with ties to management will resign their own posts rather than force the chief executive out of office. ${ }^{58}$

system and setting standards for appraising management's performance." E. MCSwEENEY, supra note 49 , at 32 .

53. J. BACON \& J. BROWN, supra note 49, at 28-29; M. MACE, supra note 47, at 95; Nutt, supra note 49, at 216. Professor Mace concludes that "In some instances a nominating committee of the board is created to identify, screen, and recommend candidates for board membership, [sic] It was found, though, that even with the presumed objectivity of a committee of outside directors, the decision as to new members is inade by the president." Id. at 195.

54. M. EISENBERG, supra note 49, at 146-47; M. MACE, supra note 47, at 98-99, 196; Nutt, supra note 49 , at 218 .

55. M. EISENBERG, supra note 49, at 146; M. MACE, supra note 47, at 99; E. MCSWEENEY, supra note 49, at 106; Nutt, supra note 49, at 219.

56. M. EISENBERG, supra note 49, at 146; J. KINLEY, supra note 52, at 16, 22; M. MACE, supra note 47, at 128; Moscow, supra note 49, at 11; Smith, Interlocking Directorates Among the "Fortune 500," ANTITRUst L. \& ECON. REv. 47, 48 (Summer 1970).

57. E. MCSWEENEY, supra note 49 , at 61.

58. M. EISENBERG, supra note 49, at 171; H. KoONTZ, supra note 47, at 128; M. MACE, supra note 47 , at $33-36$. 
Perhaps fearing that the courts would recognize this obvious source of bias, the corporations in the minority directors cases have relied largely on new outside directors with no former ties to management in establishing minority committees. ${ }^{59}$ Even this measure, however, is not sufficient to ensure an effective and unbiased committee.

\section{Problems Inherent in the Selection Process}

Newly selected outside directors also nnay be affected by biases resulting from the motivations imvolved in the selection of corporate directors-both those of the directors themselves and those of the corporation in evaluating potential directors to serve on litigation committees. Potential outside directors are not likely to accept a position for the pay, which is relatively low. ${ }^{60}$ Nor are they likely to join due to economic ties to the corporation; such ties would disqualify them from conducting an investigation of insiders. The remaming inotivations are generally personal in nature. One is the desire to learn the business of a corporation through close observation. ${ }^{61}$ Another is the stimulation or satisfaction gamed by taking on responsibility for a corporation. ${ }^{62}$ Many potential directors may be attracted by a desire for prestige, either for its own sake or for the possibilities that it may provide for future advancement in the business world. ${ }^{63}$

The likelihood that potential directors will have these motives for considering board membership may result in several problems. First, it may make it difficult for many corporations to find suitable candidates for membership on hitigation committees. The desire for prestige may not pose a problem for a corporation as prominent as Exxon. ${ }^{64}$ Corporations with such status are few in number, however, and nnost smaller

59. Maldonado v. Flynn, [1979-1980 Transfer Binder] FED. SEC. L. REP. (CCH) I 97,260 at I 96,828 (S.D.N.Y. Jan. 24, 1980); Rosengarten v. ITT, 466 F. Supp. 817, 821 (S.D.N.Y. 1979); Gall v. Exxou, 418 F. Supp. 508, 510 (S.D.N.Y. 1976). In Lewis v. Anderson, one of the three directors on the committee was not new. 615 F.2d 778, 780 (8th Cir. 1979), cert. denied, 100 S. Ct. 206 (1980).

60. See J. BACON \& J. BRown, supra note 49, at 55-56; M. EISENBERG, supra note 49, at 107. It has been suggested that compensation, averaging $\$ 11,250$ for NYSE corporations, is a factor. Note, The Business Judgment Rule in Derivative Suits Against Directors, 65 CORNELL L. REv. 600, $620 \& \mathrm{n} .101$. This level of compensation is not a real factor for the type of person who actually holds such a position, such as the directors described in note 30 supra.

61. J. BACON \& J. BRown, supra note 49, at 57-58; C. Brown \& E. SMITH, supra note 47, at 133; M. EISENBERG, supra note 49, at 102; M. MACE, supra note 49, at 104-05; Nutt, supra note 49, at 218.

62. J. BACON \& J. BRoWN, supra note 49, at 58; C. BRown \& E. SMITH, supra note 47, at 49; Nutt, supra note 49 , at 218.

63. J. BACON \& J. BRown, supra note 49, at 56; C. BRown \& E. SMITH, supra note 47, at 49; M. EISENBERG, supra note 49, at 102; M. MACE, supra note 48, at 105-06.

64. In fact, the minority directors in the Exxon case had impeccable credentials. See note 30 supra. 
corporations will not be able to confer such prestige on new directors. A directorship in a small- or medium-sized corporation will be particularly unappealing where new directors are selected for membership on a hitigation committee, since such a director will be immediately involved in a controversy. Even if the director decides im favor of management, the mvestigation itself inay create enough bitterness to ensure him a short tenure on the board. ${ }^{65}$ Moreover, the director's reputation, having been linked to the controversy, may be damaged so badly as to preclude an invitation to serve on the board of any other corporation. ${ }^{66}$ Therefore, the goal of advancement in busmess may be set back. The investigation or its aftermath also may prevent the director froin attaining either the learning experience or the enotional fulfillment he inay seek in the new post, due to frustration, bitterness, or other causes. ${ }^{67}$ Considerimg the disadvantages attached to the position, corporations inay find it very difficult to attract qualified candidates.

These same factors also inay create conflicts of interest once the new directors begin an investigation. The desire to ensure a long and fruitful relationship with the subject corporation and to bolster their prestige and prospects in business will influence the directors in favor of dropping the lawsuit. In fact, so long as a director has any reasons for accepting the position that relate to personal advancennent in the busmess world, there may be a conflict with the duty to investigate. Since the majority directors effectively control the corporation, they can influence the minority director's ability to attain his personal goals through their control over the learning and advancement opportunities available to him.

The motivations of corporations in selecting new directors also are likely to introduce biases. Corporations generally seek to gain prestige by selecting directors with excellent credentials and the right "image." 68 This desire is likely to be particularly acute if the corporation is embroiled im a shareholder suit against a majority of its board of directors. ${ }^{69}$ This motive will result im the selection of directors who are prominent figures in the busmess world, and often are or have been on the boards of other corporations. Such directors, however, usually are

65. Mace points out that consultants are often brought in during a crisis. M. MACE, supra note 47, at 32-33. One advantage of this move is that consultants will leave once the crisis is over.

66. See text accompanying note 54 supra.

67. The investigation itself may be long and difficult enough to be a major obstacle to these goals, see notes 71-77 and accoinpanying text infra, in addition to the friction and resentment that it may trigger.

68. J. BACON \& J. BRown, supra note 49, at 31; M. MACE, supra note 47, at 87-91; S. VANCE, The Corporate Director, A Critical Evaluation 63-68 (1968); Nutt, supra note 49, at 217.

69. Note the pedigrees of the minority directors referred to in soine of the cases: Gall v. Exxon, 418 F. Supp. 508, 510 n.2 (S.D.N.Y. 1976); Rosengarten v. ITT, 466 F. Supp. 817, 821 (S.D.N.Y. 1979). 
sympathetic toward the problems of other directors, and will be reluctant to condemn the actions of their comrades. ${ }^{70}$

\section{Limitations on Directors}

In addition to motivational factors, structural factors may inhibit a committee investigation. One such factor is the minority's lack of firsthand knowledge of the corporation. A second factor is the difficulty of gathering inforination concerning the lawsuit itself. Both factors affect all outside directors, whether or not they are new to the board.

The lack of firsthand knowledge is a problem in that the busmess judgment of a person who knows little or nothing about the corporation is inherently suspect. If the decision of the minority directors is to have meaning, the directors inust learn a substantial amount about the corporation's business. While it might be possible to inake a third party, such as the corporation's auditor, responsible for introducing a new director to the corporation, ${ }^{71}$ the present practice is for management to perforn this function. ${ }^{72}$ A detailed introduction conducted by management is unlikely to give the director an unbiased perspective, however, smce management will be likely to present infornation on the corporation in the light most favorable to its interests.

In addition to knowledge about the corporation in general, a sound evaluation of a cause of action requires a long and detailed investigation into the merits of the claim and the facts that led to it. The investigations that the courts approved in the recent cases required considerable amounts of time. ${ }^{73}$ Most directors, however, spend only a limited amount of time on their directorial responsibilities, ${ }^{74}$ largely as a result of their unwillingness or inability to give more of their time to the corporation. ${ }^{75}$ If the directors barely have the time to discharge their normal duties, their ability to undertake an extraordinary and de-

70. See Dent, supra note 7, at 112 ("Most outside directors share similar social and professional backgrounds and general attitudes with their inside director colleagues [, and] are unlikely to look favorably on shareholder interference with management generally, or on derivative suits seeking to foist liability on corporate directors.") (footnotes omitted).

71. See Nutt, supra note 49 , at 220.

72. C. BRown \& E. SMITH, supra note 49, at 88-89; Leech \& Mundheim, The Outside Director of the Publicly Held Corporation, 31 Bus. LAw. 1799, 1811-12 (1976); Nuth, supra note 49, at 219.

73. Maldonado v. Flynn, [1979-1980 Transfer Binder] FED. SEC. L. REP. (CCH) I] 97,260 at 96,829 (S.D.N.Y. Jan. 24, 1980); Rosengarten v. ITT, 466 F. Supp. 817, 824-25 (S.D.N.Y. 1979); Abbey v. Coutrol Data Corp., 460 F. Supp. 1242, 1244 (D. Minn. 1978), aff'd, 603 F.2d 724 (8th Cir. 1979), cert. denied, 444 U.S. 1017 (1980); Gall v. Exxon, 418 F. Supp. 508, 511 (S.D.N.Y. 1976); Lasker v. Burks, 404 F. Supp. 1172, $1175-76$ (S.D.N.Y. 1975), rev'd, 567 F.2d 1208 (2d Cir. 1978), rev'd, 441 U.S. 471 (1979).

74. M. EISENBERG, supra note 49, at 142-43. See also Solderquist, supra note 49, at 1352-54.

75. C. BRown \& E. SMITH, supra note 49, at 40-41; M. MACE, supra note 47, at 91-93; Moscow, supra note 49, at 11; Solderquist, supra note 49, at 1351-52. 
tailed imvestigation will be even more limited. Despite the apparent success of the corporations involved in recent cases of this type, it will not be easy for corporations to find outside directors who are willing to spend the time necessary for an adequate investigation. ${ }^{76}$ Unfortunately, the recent precedents may lead courts to approve dismissals in cases where the imvestigation was far from exhaustive.

Even if the corporation finds directors able and willing to take the time to conduct an adequate investigation, they inay not have access to the necessary information. Although senior management may support an investigation, ${ }^{77}$ lower managers may, out of misplaced loyalty to their semors, self-protection, or ignorance of the mvestigation, withhold information from the investigating directors. The directors will have no compulsory mechanism for obtaining information in the hands of persons outside the corporation, such as former employees, simce they lack the judicial powers given to parties during discovery. Such information may be deliberately kept from the directors, or simply overlooked by them.

This last poimt accents the need for judicial involvement in the mvestigation. Even assuming that the minority directors are willing and able to conduct a thorough imvestigation, and that the corporation does all that it can to assist them, third parties, subject neither to the majority nor to the minority directors, can frustrate an mquiry. By contrast, many of the courts' formal discovery mechanisms are directed toward the problems of the availability and veracity of third party evidence, and their use would result in a nore thorough investigation.

\section{III}

\section{The Use of a Settlement Procedure}

The various factors discussed above indicate that the minority directors are unlikely to investigate completely and independently a claim agamst the majority directors. Consequently, a motion by minority directors to dismiss such a claim, as in the ininority directors cases, should not be accorded a presumption of validity under the business judgment rule.

Several courts ${ }^{78}$ and commentators ${ }^{79}$ have accepted the kind of

76. C. BROWN \& E. SMITH, supra note 49, at 49, 123, 132-33; M. MACE, supra note 47, at 93.

77. The outside directors are dependent on the corporate management for access to information. M. EisENBERG, supra note 49, at 143-44; M. MACE, supra note 47, at 30-32; see deHaas v. Empire Petroleum Corp., 286 F. Supp. 809, 814 (D. Colo. 1968).

78. Abella v. Universal Leaf Tobacco Co., 495 F. Supp. 713 (E.D. Va. 1980) (applying Virginia law); Maher v. Zapata Corp., 490 F. Supp. 348 (S.D. Tex. 1980) (applying Delaware law); Maldonado v. Flynn, 413 A.2d 1251 (Del. Ch.) (applying Delaware law), , contingently dismissed on other grounds, 417 A.2d 378 (Del. Ch. 1980). The opinion of the Second Circuit to the same effect in Lasker v. Burks, 567 F.2d 1208 (2d Cir. 1978), was unanimous but was reversed in Burks v. 
policy analysis offered above and have concluded that the power of these special litigation committees slould be limited. However, they have felt compelled by the holdings of Burks to attack the problem througl changes in state law, inost commonly the elimination of the business judgment rule in such situations. This approach lias several disadvantages.

First, such a piecemeal approach is almost certain to bring only slow, incremental, and incomplete changes in the law of the various states. Sucli changes are not likely to be adopted in all states, ${ }^{80}$ and where adopted, are not likely to be uniform in effect. The existence of such varying standards would inean that the success of a claim brought agamst majority directors would depend to soine extent on the law of the state of imcorporation. The importance of the applicable state law would be as great in the federal courts as in the state courts, smce under Burks the federal courts inust look to state law in determining the authority of the minority directors to dismiss derivative suits. The need for federal court interpretation of state law in this area may raise separate problems-the possibility of federal courts making incorrect interpretations of state cases, statutes, and policies, and the confusion that would result. These problems have already arisen in at least one case. ${ }^{81}$

Moreover, elimination of the business judgment rule in all minority director cases is not the optimal solution to the problems presented by these cases, particularly if it means that the judgment of litigation committees would be given no weight at all. Corporations will always be subject to strike suits. The courts will be able to dismiss some such suits as frivolous on their faces, but for many the issue will not be as clear. Complete disregard of the recommendation of the litigation committee would require that all derivative suits, as long as they are

Lasker, 441 U.S. 471 (1979). The opinion in Auerbach v. Bennett, 64 A.D.2d 98, 408 N.Y.S.2d 83 (1978), to the same effect, inet the same end. 47 N.Y.2d 619, 393 N.E.2d 994, 419 N.Y.S.2d 920 (1979).

79. See note 7 supra; Buxbaum, Conflict-of-Interst Statutes and the Need for a Demand on Directors in Derivative Actions, 68 CALIF. L. Rev. 1122, 1131 n.50 (1980) (review of decision by new board not to uudo an earher transaction itself challengeable only as a waste of assets).

80. Since Burks, the New York courts have responded by applying the business judgment rule to the recommendation of a committee of minority directors, Auerbach v. Bennett, 47 N.Y.2d 619, 393 N.E.2d 994, 419 N.Y.S.2d 920 (1979), but the first state court to declare the law of Delaware held that the business judgment rule did not apply. Maldonado v. Flynn, 413 A.2d 1251 (Del. Ch.), contingently dismissed on other grounds, 417 A.2d 378 (Del. Ch. 1980). The federal court in Maher v. Zapata Corp., 490 F. Supp. 348 (S.D. Tex. 1980) (applying Delaware law), reached the latter result independently of Maldonado. See also Dent, supra note 7, at 97 (legislative tendency to obstruct rather than aid derivative suits).

81. The holdings of Maldonado (Del. Ch.) and Maher contradicted the prior attempts of federal courts to apply Delaware law in minority directors cases. See, e.g., Abbey v. Control Data Corp., 603 F.2d 724 (8th Cir. 1979), cert. denied, 444 U.S. 1017 (1980); Maldonado v. Flynn, [19791980 Transfer Binder] FED. SEC. L. REP. (CCH) ๆ 97,260 (S.D.N.Y. 1980). 
not void on the pleadings, go through the full discovery process before the corporation would have an opportunity to have them dismissed. Such a rule would unnecessarily waste the resources of both the corporation and the judicial system. Thus, im those derivative suits that imvolve colorable but not clearly meritorious clamis, the courts should give some weight to the judgment of the minority directors, but should not disnriss the actions based on their recommendation alone.

These problems can be avoided through the use of the Rule 23.1 settlement procedure im considering the request of a special litigation committee for summary judgment. The proper application of Rule 23.1 would provide a single standard for all such cases brought in the federal courts. In addition, since many states have adopted rules similar to Rule 23.1, adoption of the interpretation urged in this Cominent nnight influence the procedural law of many states in the same direction. ${ }^{82}$ More important, however, is the fact that the settlement procedure would give the federal courts the authority to review the merits of the proposals of minority directors im a flexible fashion, ${ }^{83}$ and would provide shareholders with the safeguards of notice and an opportunity to imvestigate the merits of the action on their own.

\section{A. Rule 23.1}

Federal Rule of Civil Procedure 23.1 provides that shareholder derivative suits "shall not be disnnissed or compromised without the approval of the court, and notice of the proposed dismissal or compronnise shall be given to shareholders or members in such inanner as the court directs." 84 Under this Rule, the courts generally require that notice be given to the shareholders and that any shareholders that object to the coinpromise or dismissal be given an opportumity to dis-

82. See, e.g., Ala. R. Civ. P. 23.1 (1975); ARIz. R. Civ. P. 23.1 (West 1973); Colo. R. Civ. P. 23.1 (1973); IDAHo R. CIV. P. 23(f) (1980); IND. TRIAL R. 23.1 (1973); MASS. R. Clv. P. 23.1 (West 1978); MINN. R. CIv. P. 23.06 (West 1980); Nev. R. Civ. P. 23.1 (1979) (all replicas of FED. R. Crv. P. 23.1).

83. Soine federal courts acknowledge that they may overturn a business judgment, but limit that power to cases in which the judgment is so erroneous as to indicate constructive fraud or some other form of bad faith. United Copper Sec. Co. v. Amalgamated Copper Co., 244 U.S. 261, 264 (1917); Ash v. IBM, 353 F.2d 491, 493 (3d Cir. 1965), cert. denied, 384 U.S. 928 (1966). Also, while the minority directors cases do permit the plaintiff to inquire into the qualifications and independence of the minority directors, Abbey v. Control Data Corp., 460 F. Supp. 1242, 1244 (D. Minn. 1978), aff'd, 603 F.2d 724 (8th Cir. 1979), cert. denied, 444 U.S. 1017 (1980), Gall v. Exxon, 418 F. Supp. 508, 519-20 (S.D.N.Y. 1976), Lasker v. Burks, 404 F. Supp. 1172, 1180 (S.D.N.Y. 1975), rev'd, 567 F.2d 1208 (2d Cir. 1978), rev'd, 441 U.S. 471 (1979), that inquiry cannot discover or prove that directors, although not acting in bad faith, may not be acting in the best interests of the corporation. The courts appear to recognize that some review is needed. Unfortunately, this review is so restricted that it is not sufficient to enable the courts to reach the merits of the cases.

84. FED. R. Crv. P. 23.1. 
cover the facts underlying the complaint and to express their objections at a court hearing.

The courts have applied this procedure to all proposed settleinents of derivative actions. ${ }^{85}$ However, the treatment of dismissals depends on whether the dismissal is voluntary or involuntary. Where the dismissal is voluntary as to the plaintiff, the courts use the procedure. The courts have established an exception to the requirements of Rule 23.1, however, where the dismissal is involuntary as to the plaintiff, as in dismissals for failure to state a claim ${ }^{86}$ or for lack of prosecution. ${ }^{87}$ This difference is due to the policies behind the Rule's notice and review requirements.

In shareholder derivative suits, the shareholder-plaintiff, similar to the named plaintiff in a class action, is representing all of the shareholders. As in a class action, there is a danger that the plaintiff will attempt to dispose of the suit in the manner most favorable to his own interests, but harmful to those of the other shareholders and the corporation. ${ }^{88}$ This danger is nost clearly presented where the shareholder settles the suit. The plaintiff may become intimidated by the scale of the litigation, or may react to pressure or secret payments from the defendants, or may sunply want to obtain a quick payoff and get out of the derivative suit. ${ }^{89}$ In such a case it is important for the court to review the settlement agreement, not only to ensure that it represents the interests of the corporation fairly, but also to allow the other shareholders to object if they feel that their interests are not being represented adequately.

In a settlement agreement, the shareholder-plaintiff gets a definite, immediate payoff, which provides a clear incentive for him to end the lawsuit even if the settlement is not optimal for the corporation. Therefore, the courts should approve such settlements only after investigatimg their fairness to all parties. Such caution is also appropriate in approvmg voluntary dismissals. The plaintiff may become intimidated or may accept an out-of-court payinent froin the defendant and attempt to end

85. See, eg., Girsh v. Jepson, 521 F.2d 153 (3d Cir. 1975); Birnbaum v. Birrell, 17 F.R.D. 409 (S.D.N.Y. 1955).

86. Smith v. Industrial Sec. Corp., 49 F. Supp. 959 (D. Conn. 1943); Mullins v. De Soto Sec. Co., 45 F. Supp. 871 (W.D. La. 1942), rev'd on other grounds, 136 F.2d 55 (5th Cir. 1943); Massaro v. Fisk Rubber Corp., 36 F. Supp. 382 (D. Mass. 1941).

87. See Papilsky v. Berndt, 333 F. Supp. 1084 (S.D.N.Y. 1971), cert. denied, 409 U.S. 1077 (1972); Saylor v. Lindsley, 274 F. Supp. 253 (S.D.N.Y. 1967), rev'd on other grounds, 391 F.2d 965 (2d Cir. 1968).

88. Note the similarity between Rule 23(e) (dismissal or compromise of class action) and the last sentence of Rule 23.1.

89. See Wolf v. Barkes, 348 F.2d 994, 996 (2d Cir. 1965); Birnbaum v. Birrell, 17 F.R.D. 409, 411 (S.D.N.Y. 1955) (collusion). 
the suit. ${ }^{90}$ Notice is required "to ensure that the dismissal of the derivative suit is in the best interests of the corporation and the absent stockholders."

The courts perceive no such dangers when the dismissal is involuntary as to the plaintiff. If the plaintiff is forced to drop the suit, there would seem to be no grounds for the suspicion that the plaintiff is sacrificing the interests of the other shareholders due to intimidation, fatigue, or collusion, since he did not seek dismissal of the suit.

The courts carry this distinction between voluntary and involuntary dismissals into the granting of summary judgments. When "the shareholder-plaintiff consents to the entry of a summary judginent against him, this may be viewed as equivalent to a voluntary dismissal for purposes of the Rule 23.1 notice provisions." 92 Thus, the courts have required notice and a hearing before granting a voluntary suinmary judgment. ${ }^{93}$

\section{B. Applicability to the Minority Directors Cases}

In the mimority directors cases, the district courts granted summary judgment on the strength of the recommendations of the mmority directors without following the procedures established in Rule 23.1. The Supreme Court considered the applicability of the rule to these cases in Burks v. Lasker, but disposed of it in a single footnote. ${ }^{94}$ The Court leeld that since summary judginent in that situation was involuntary, notice was not necessary.

In reaching this conclusion, the Court relied on Wolf $v$. Barkes. ${ }^{95}$ In that case a shareliolder had filed a derivative suit against a corporation and its officers, challenging compensation arrangements between them. The corporation sought to settle out-of-court with some of the defendant officers, and the derivative plaintiff sought to enjoin any settlement of the claims unless the court approved the settlements pursu-

90. Cramer v. General Tel. \& Elec. Corp., 582 F.2d 259, 268-69 (3d Cir. 1978), cert. denied, 439 U.S. 1129 (1979); Webster Eisenlohr, Inc. v. Kalodner, 145 F.2d 316, 320 (3d Cir. 1944), ccrt. denied, 325 U.S. 867 (1945); Birnbaum v. Birrell, 17 F.R.D. 409, 411 (S.D.N.Y. 1955).

91. Papilsky v. Berndt, 466 F.2d 251, 258 (2d Cir.), cert. denied, 409 U.S. 1077 (1972).

92. 7A C. WRIGHT \& A. MILLER; supra note $17, \S 1839$, at 436.

93. Papilsky v. Berndt, 466 F.2d 251, 258 (2d Cir.), cert. denied, 409 U.S. 1077 (1972); Certain-Teed Prods. Corp. v. Topping, 171 F.2d 241, 243 (2d Cir. 1948); Brendle v. Smith, 7 F.R.D. 119,120 (S.D.N.Y. 1946).

94. 441 U.S. 471,485 n.16 (1979).

95. 348 F.2d 994 (2d Cir. 1965). The Court also cited J. Moore, Federal Practice and C. Wright \& A. Miller, Federal Practice and Procedure for support. Neither of these cominentators actually supports the Court's conclusion; in fact, they oppose the result obtained. "Unless the dismissal can be analogized to a dismissal for lack of jurisdiction, or to dismissal after an adversarial determination on the inerits, with adequate representation, then no exception should be recognized and notice should be required." 3B J. MOORE, supra note 17, I] 23.1.24[2], at 23.1131. To the same effect is 7A C. WRIGHT \& A. MILLER, supra note $17, \S 1839$, at 436. 
ant to Rule 23.1. The plaintiff argued that the proposed settlement of the claims would give the officer-defendants in the derivative suit a "presumptively vahid defense" and thus would impair her chances of recovery. ${ }^{96}$ Judge Friendly, speaking for the Second Circuit Court of Appeals, held that the rule did not extend to such cases, noting that even though the settlement might be detrimental to the derivative suit, "[n]o one has sought to dismiss or compromise the class suit."97 The suit would continue, and if the officers could be shown to have engaged in self-dealing, the plaintiff could still recover.

Judge Friendly carefully distimguished the out-of-court settlement in Wolf from the situation presented in Birnbaum v. Birrell. ${ }^{98}$ That case involved a derivative action brought origmally agamst the directors of a corporation. After the suit was filed, the corporation's board of directors was replaced with a new board, which all parties admitted to be "wholly divorced" from the activities underlying the derivative action. ${ }^{99}$ The new board presented to the court a settlement that it had reached with the defendants in the suit, but the court refused approval because the notice to the shareholders had been inadequate. The court noted that some commentators had argued that if the directors of a corporation, in their sound judgment, approved a settlement, the court need not inquire further into the merits of the case. The court dismissed this argument because of its lack of case support, and held that while the judgment of the board was a factor, it was not conclusive as to the fairness of the proposed settlement. The court then concluded that despite the apparent dismterestedness of the new board, it could avoid all taint of self-imterest in the settlement only by becoming a third party to the settlement. Thus, "the proponents of a compromise must bear the burden of proving that it is fair and to the best interests of the corporation."100 Under similar circumstances, several other courts have required boards of directors to seek court approval of proposed settlements that would require the dismissal of the derivative suits involved. ${ }^{101}$

If Burks is analogized to a settlement, it clearly fits within the Birnbaum rather than the Wolf line. In Burks the corporation was not simply trymg to settle claims related to the allegations in the derivative suit, as im Wolf. Rather, it was trying to dispose of the derivative suit itself, as was the case in Birnbaum. The danger to the shareholder

96. 348 F.2d at 996.

97. Id.

98. 17 F.R.D. 409 (S.D.N.Y. 1955).

99. Id at 410 .

100. Id at 412 .

101. See Denicke v. Anglo Cal. Nat'1 Bank, 141 F.2d 285 (9th Cir.), cert. denied, 323 U.S. 739 (1944); Berger v. Dyson, 111 F. Supp. 533 (D.R.I. 1953). 
plaintiff was not that his claim might be more difficult to prove, as in Wolf, but that his claim would be terminated altogether. To be consistent with Wolf and Birnbaum, then, the Burks court should have inandated compliance with the requirements of Rule 23.1.

The Burks Court also erred in lolding that the summary judgment was involuntary. It was clearly not involuntary as to the mimority directors, smce they had brought the motion. The voluntariness of the directors is critical because in bringing the inotion for summary judgment they in effect assumed the role ordmarily occupied by the sharelolder-plamtiff im a Rule 23.1 case. The reasoning behind the litigation committees' motions for dismissal is similar to that behind a derivative plaintiff's motion for a voluntary disimissal. Both are based on the conclusion that the merits of the cause of action, as reflected in the expected recovery, do not warrant mcurring the risks and expenses imvolved im the litigation. ${ }^{102}$ Thus, the minority directors in effect replaced the plaimtiff im seeking a voluntary suminary judgment. ${ }^{103}$

Such a voluntary motion does not qualify for exemption from the Rule 23.1 requirements. Nor, as a matter of policy, should it be exempt, smce the minority directors are as likely to be bought out or intimidated as a derivative plaimtiff. ${ }^{104}$ The minority directors may shight the corporate interests if they grow famt-hearted at the possible costs of the litigation-not only the objective economic costs, but also the personal subjective costs sucli as conflicts witl other directors, the withering of personal opportumities, or the time commitment necessary to pursue it. Also, they may receive subtle forms of payoff from the corporate imsiders in exchange for a settlement contrary to the interests of the corporation.

The Burks Court apparently tried to sidestep the voluntariness of the directors' motion by relying on the fact that the motion was involuntary as to the shareholder plamtiff. Considering the motion as agaimst the plaintiff does not justify the granting of summary judgment without following the Rule 23.1 procedure, lowever, since the plaintiff

102. Note the very similar reasons offered by the directors in the minority directors cases. Abbey v. Control Data Corp., 603 F.2d 724, 727 (8th Cir. 1979), cert. denied, 444 U.S. 1017 (1980); Rosengarten v. ITT, 466 F. Supp. 817, 822 (S.D.N.Y. 1979); Gall v. Exxon, 418 F. Supp. 508, 524 (S.D.N.Y. 1976); Lasker v. Burks, 404 F. Supp. 1172, 1177 (S.D.N.Y. 1975), rev'd, 567 F.2d 1208 (2d Cir. 1978), rev'd, 441 U.S. 471 (1979).

103. Although the same reasoning might seein to apply to cases in which the inajority of the board is disinterested, such cases are generally dismissed at the deinand stage, rather than proceeding to summary judgment, a result that is justified by the defendants' lack of control over the proxy machinery. See text following note 53 supra.

104. Note that the special deference given to directors under the business judgment rule, on which the Court relied in Burks, is a rule of state substantive law that, in the absence of the Erie doctrine, see text accoinpanying note 41 supra, has no compelling force of its own in the interpretation of the Federal Rules of Civil Procedure. 
had had no opportunity to conduct discovery. The courts have consistently held that an involuntary summary judgment should not be granted to defendants under circumstances such as these until the plamtiff has had a chance to engage in discovery, ${ }^{105}$ since all of the facts concerning the case are initially in the hands of the defendants. ${ }^{106}$

\section{Using the Settlement Procedure}

In applymg the Rule 23.1 procedure, the minority directors would have the burden of showing good cause for a disinissal, by establishing, for example, that the corporation would be unlikely to recover the costs of bringing suit. The court should give some weight to the business judgment of the directors and look to the actual merits of the case, but should stop judicial review short of a full trial. The central feature of the process is flexibility, as illustrated by an examination of the procedure's components. ${ }^{107}$

105. Alabama Farm Bureau Mut. Cas. Co. v. American Fidelity Life Ins. Co., 606 F.2d 602, 609 (5th Cir. 1979), cert. pending, No. 79-1362, 446 U.S. 933 (1980); Sclioenbaum v. Firstbrook, 405 F.2d 215, 218 (2d Cir. 1968) (en banc), cert. denied, 395 U.S. 906 (1969); Loeb v. Whittaker Corp., 333 F. Supp. 484, 487 (S.D.N.Y. 1971); cf. Cohen v. Ayers, 596 F.2d 733, 743 \& n.20 (7th Cir. 1979) (summary judgment upheld where plaintiff had over a year in whicls to conduct discovery). Contra, S \& S Realty Corp. v. Kleer-Vu Indus., Inc., 575 F.2d 1040, 1044 (2d Cir. 1978) (grounds for judginent amounted to failure to state a claim); Goldberg v. Meridor, 567 F.2d 209, 213 (2d Cir. 1977), cert. denied, 434 U.S. 1069 (1978) (applying the summary judgment considerations of Schoenbaum to reverse as an abuse of discretion a refusal to grant leave to annend).

106. This point implies that the mimority directors could wait for the plaintiff to finisl discovery, and then obtain a summary judgment without notice or a hearing. While there may be cases in which obtaining a quick dismissal is not worth the expense of notice, the minority directors cases present situations in which the boards of directors were unwilling to wait so long to terminate the suit.

107. The placement of the burden of proof on mimority directors would actually bring federal court procedure closer to state law than does the Court's decision in Burks. As was slown in Section II, the decisions of the minority directors in these cases caunot be considered truly disinterested. Thus, if it were correct to apply state substantive law, the decisions of the minority directors could be analogized to interested director transactions-in which one or nore directors have engaged in business dealings with the corporation of which they are directors. The courts have traditionally put the burden of proving the fairness of the transaction on the interested director. Pepper v. Litton, 308 U.S. 295, 306 (1939); 19 AM. JUR. 2d Corporations § 1288 (1965). Thirty-one states have passed statutes regarding sucl transactions.

ARIz. Rev. Stat. ANn. § 10-041 (1977); Cal. Corp. Code § 310 (Deering 1977); ConN. Gen. Stat. AnN. § 33-323 (West 1979); Del. Code AnN. tit. 8, § 144 (1974); Fla. Stat. AnN. §607.124 (West I977); GA. Code ANN. § 22-716 (1977); IDAHO CODE § 30-1-41 (1980); IND. CODE ANN. § 23-1-10-6 (Burns 1979); IowA Code ANN. \$ 496A.34 (West Supp. 1980-81); KaN. Stat. ANN. § 17-6304 (1974); KY. REv. Stat. § 271A.205 (Supp. 1980); LA. Rev. Stat. ANN. § 12:84 (West 1969); ME. Rev. Stat. ANN. tit. 13-A, $\$ 717$ (1974); MD. CoRP. \& Ass'NS. Code ANN. § 2-419 (Supp. 1980); Mich. CoMp. LAws ANN. § 450.1545 (1973); Miss. Code ANN. § 79-367 (1972); Neb. Rev. STAT. § 21-2040.01 (1977); Nev. REv. Stat. § 78.140 (1979); N.J. STAT. ANN. § 14A:6-8 (West 1973); N.Y. Bus. CoRP. LAw $\$ 713$ (McKinney 1971); N.C. GeN. STat. §55-30 (1975); OHIO Rev. Code ANN. § 1701.60 (Page 1953); OR. Rev. STAT. $\$ 57.265$ (1979); 15 PA. Cons. Stat. ANN. § 409.1 (Purdon 1968); R.I. GeN. LAws § 7-1.1-37.1 (1969); S.C. CodE § 33-13-160 (1976); TENN. Code ANN. § 48-816 (1979); Vr. STAT. ANN. tit. 11, § 1888 (1973); VA. 
The requirement of notice to shareholders would serve the same purpose as the requirement of notice to the class in a class action does-it would enable the parties whose interests are being represented by the plaintiff to protect themselves against an unacceptable dismissal or settlement of their claims. ${ }^{108}$ The courts generally require that notice be mailed to each shareholder of record, ${ }^{109}$ but this standard may be relaxed at the discretion of the court. ${ }^{110}$ Thus, where the number of shareholders is large, some commentators have suggested that publication coupled with individual notice to only a sampling of the shareholders might be sufficient, ${ }^{11}$ cuttimg the costs of notice by relying on a shareholder sample to provide a response representative of the whole body. A few courts have even gone so far as to require only notice by publication. ${ }^{112}$

Any shareholders who object to the recommendation of the minority directors would be able to engage in discovery as to the merits of the claim as well as the independence of the directors. ${ }^{113}$ In most cases, only the shareholder-plaintiff would actually engage in discovery, although other shareholders might feel that their imterests are threatened and want to participate as well. Possibly the inost important facet of such discovery would be the ability to depose persons who are not parties to the action, ${ }^{114}$ although the service of interrogatories ${ }^{115}$ and re-

CODE § 13.1-39.1 (1950); W. VA. Code § 31-1-25 (Supp. 1980); WIs. STAT. ANn. § 180.355 (West Supp. 1980-81). Many of the recently passed statutes purport to allow ratification of an "interested director transaction" by the disinterested directors as a method of overcoming the interested director's burden of proving fairness. Nevertheless, the courts have tended to insist that the intcrested directors prove fairness regardless of statutes apparently to the contrary. Remillard Brick Co. v. Remillard-Dandini, 109 Cal. App. 2d 405, 418, 241 P.2d 66, 74 (1952); Flieglcr v. Lawrence, 361 A.2d 218, 221-22 (Del. 1976); Coinolli v. Comolli, 241 Ga. 471, 474, 246 S.E.2d 278 (1978); Hoh-Rest, Inc. v. Treloar, 217 N.W.2d 517, 525 (lowa 1974); Newton v. Hornblower, Inc., 224 Kan. 506, 522, 582 P.2d 1136, 1146 (1978); Bulbulia \& Pinto, Statutory Responses to Interested Directors' Transactions: A Watering Down of Fiduciary Standards?, 53 Notre Dame LAw. 201, 204 (1977); Note, Section 21-2040.01: Interested Director Transactions and Considerations of Fairness, 58 NEB. L. REv. 909, 913-15 (1979). Also, the Kentucky statute requires that the transaction not be "manifestly unfair" before ratification is allowed, KY. REv. STAT. \& 271A.205(1)(b) (Supp. 1980), and the Vermont statute requires good faith, VT. STAT. ANN. tit. 11, § 1888 (1973). The Mississippi statute allows for ratification only by the shareholders. Miss. CODE ANN. § 79-3-67 (1972).

108. 7A C. WRIGHT \& A. MILLER, supra note 17, \& 1797, at 226-27.

109. Boggess v. Hogan, 410 F. Supp. 433, 442 (N.D. Ill. 1975).

110. Blau v. Berkey \& Berkey Photo, Inc. [1967-69 Transfer Bimder] Fed. SEC. L. REP. (CCH) I 92,264 (S.D.N.Y. 1968).

111. See, e.g., 7A C. Wrught \& A. MilLeR, supra note 17, § 1839, at 431.

112. Blau v. Brown \& W. Nuciear, Inc., [1967-69 Transfer Binder] Fed. SEC. L. REP. (CCH) I 92,263 (S.D.N.Y. 1968); Blau v. Allen, 171 F. Supp. 669 (S.D.N.Y. 1959).

113. Girsh v. Jepson, 521 F.2d 153, 157 (3d Cir. 1975); Saylor v. Lindsley, 456 F.2d 896, 904 (2d Cir. 1972); Colicn v. Young, 127 F.2d 721, 724 (6th Cir. 1942), cert. denied, 321 U.S. 778 (1944).

114. Fed. R. Civ. P. 30.

115. FED. R. Crv. P. 33. 
quests for documents ${ }^{116}$ also might bring to light valuable infornation that could have eluded the minority directors. The trial court would retam control over this process, as it has the discretion to limit discovery in accordance with the scope of the judicial review of the settlement. ${ }^{117}$

The court would have considerable discretion in determining the extent of its review. While concerns for judicial economy and the conservation of the corporation's assets would limit judicial review, ${ }^{118}$ the court would reach the merits of the claim, and approval of the settlement would be in the court's discretion. ${ }^{19}$ This ability to consider the merits of the action is the most important advantage of the settlement hearing.

The court's duty in reviewing the minority directors' recommendation would be to consider all of the facts, ${ }^{120}$ using the directors' judgment as a factor, but not a conclusive one. ${ }^{121}$ The court's analysis should be directed to the balance between the inerits of the action-i.e., the expected recovery-and the expected costs of the litigation. ${ }^{122}$

116. FED. R. Crv. P. 34.

117. Saylor v. Lindsley, 456 F.2d 896, 904 (2d Cir. 1972); Cohen v. Young, 127 F.2d 721, 726 (6th Cir. 1942), cert. denied, 321 U.S. 778 (1944); Glicken v. Bradford, 35 F.R.D. 144, 148 (S.D.N.Y. 1964).

118. E.g., Greenspun v. Bogan, 492 F.2d 375, 381 (1st Cir. 1974); Lewis v. Newman, 59 F.R.D. 525, 527 (S.D.N.Y. 1973); Schleiff v. Chesapeake \& Ohio Ry., 43 F.R.D. 175, 178 (S.D.N.Y. 1967).

119. See Saylor v. Lindsley, 456 F.2d 896, 904 (2d Cir. 1972) (the court may consider the merits); Newman v. Stein, 464 F.2d 689, 693 (2d Cir.), cert. denied, 409 U.S. 1039 (1972); West Virginia v. Chas. Pfizer \& Co., 440 F.2d 1079, 1086 (2d Cir.), cert. denied, 404 U.S. 871 (1971) (approval is in the court's discretion).

120. Protective Comm. v. Anderson, 390 U.S. 414, 424 (1968); Shlensky v. Dorsey, 574 F.2d 131, 147 (2d Cir. 1978). Protective Committee deals with a bankruptcy case, but the standards of review for settlements and bankruptcy cases are the same. Newman v. Stein, 464 F.2d 689, 692 n.6 (2d Cir.), cert. denied, 409 U.S. 1039 (1972).

121. See, e.g., Norman v. McKee, 431 F.2d 769, 778 (9th Cir. 1970) (not a conclusive factor), cert. denied, 401 U.S. 912 (1971); Schleiff v. Chesapeake \& Ohio Ry., 43 F.R.D. 175, 178 (S.D.N.Y. 1967) (a factor).

122. Protective Comm. v. Anderson, 390 U.S. 414, 424-25 (1968); Shlensky v. Dorsey, 574 F.2d 131, 147 (2d Cir. 1978). The motion to dismiss in a settleinent procedure only requires that the minority directors show that continuing the higation will harm the corporation, in that even if the hitigation is won, the recovery will not repay the costs of the suit. The burden in a settlement procedure is lighter than that required in a motion for summary judgment. See FED. R. Clv. P. 56. A motion for summary judgment will not be granted unless there is no material dispute of fact and plaintiff has no basis for recovery. Adickes v. Kress \& Co., 398 U.S. 144, 157 (1970).

Possible objections to the use of the settlement procedure are likely to center on the increased time delays and costs that it would bring. Under the flexible guidelines adopted by the courts, lowever, if the derivative suit is unfounded, the resources devoted to the action would be minimal. If the suit is meritorious, the extra expense is well justifled. In either case, the procedure is superior to the current trend toward dismissing the suit on the basis of the directors' motion alone.

A related arguinent is that the procedure would encourage strike suits. However, since illfounded claims can still be dismissed with no more than reasonable delay and expense, the use of 


\section{CONCLUSION}

The minority directors cases have drawn the business judgment rule from cases applying the demand requirement of Rule 23.1, and have used it to justify the granting of suminary judgments against derivative plamtiffs. However, these are cases im which demand is excused because a majority of the directors are defendants im the suit. This novel use of the business judginent rule in the absence of the deunand requirement cannot be justified under the circumstances in which inost board rooms operate. The courts should not defer to the decisions of the minority directors because the minority's judgment is likely to be influenced by their ties to the defendants, by the process of their selection (includimg the aspirations of the minority and inajority directors), by the limits on their time and knowledge, and by the defendants' control over the proxy machinery. In the face of such factors, impartial review by the courts is imperative.

The correct procedure in these cases would be to treat the ininority directors' notion to dismiss as a proposal for settleinent. The directors, after filing such a motion, would be required to give notice to the shareholders, who would have an opportunity to object to the proposed settlement at a limited hearing. The court would conduct a limited review of the merits of the cases, at which the directors would have the burden of supporting the notion. Thus, Rule 23.1 would be enforced in accordance with its underlying policies, while the courts could disiniss strike suits. Most importantly, the plaintiff would have an opportunity to present a nonfrivolous claim at an impartial hearing. $\dagger$

James H. Shnell*

Rule 23.1 should not contribute to the settlement value of a claim brought in bad faith. At least the corporatiou should be able to stop any nonmeritorious suit without full discovery procedures.

$\dagger$ Editors' Note: Late in the publication process, the Delaware Supreme Court handed down an opinion in Zapata Corp. v. Maldonado, No. 113, 1980 (Del. May 13, 1981), rev'g sub nom. Maldonado v. Flynn, 417 A.2d 378 (Del. Ch. 1980). The opinion calls for a de novo judicial review of a corporate decision to termmate the derivative litigation. This review procedure is explicitly analogized to judicial review of litigation settlement. Id., slip op. at 23-24. For a discussion of this analogy and the inechanics of a procedure based on a settlement model, see text accompanyming notes 78-122 supra.

* B.A. 1972, Stanford University; M.B.A. 1978, Harvard University; third-year student, Boalt Hall School of Law. 